МАЗУР В.В., РЕЗВОВА О.В.

\title{
ОСОБЛИВОСТІ РЕАЛІЗАЩЇ̈ ПРАВ ТА ОБОВ'ЯЗКІВ БАТЬКІВ ЩОДО ВИХОВАННЯ ДИТИНИ ТА МЕЖІ ЇХ ЗДІЙСНЕННЯ
}

Одним із важливих і значних досягнень громадянського суспільства $є$ проголошення сімейних прав та обов'язків батьків і дитини на законодавчому рівні. Законодавством закріплені положення щодо пріоритету інтересів дитини над інтересами батьків. І хоча права і обов'язки в обох батьків є рівними та взаємними, кожен із батьків повинен контролювати процес виховання дитини, що здійснюється іншою стороною. Тому у статті проаналізовано проблемні аспекти та особливості реалізації прав та обов'язків батьків щодо виховання дитини.

Відповідно до ст. 12 Цивільного кодексу України особа здійснює свої цивільні права вільно, на власний розсуд, тому у статті автори вважають за потрібне з'ясувати поняття суб'єктивного права, при цьому аналізують думку інших науковців і висловлюють власні думки щодо обставин реалізації таких прав.

За загальним правилом, передбаченим Конституцією України, не допускається звуження вже існуючих прав і свобод особи, але при цьому свобода особи має узгоджуватися зі свободою інших людей та бути обгрунтованою згідно вимог суспільства. Поряд із цим у низці статей Конституції передбачена можливість обмеження деяких прав і свобод людини і громадянина за наявності певних обставин. При визначенні моральних меж здійснення суб'єктивних прав основну роль повинні відігравати загальнолюдські цінності.

У цивільному законодавстві України міститься загальне правило, яке встановлює межі здійснення цивільних прав. Так, цивільні права особа має здійснювати у межах, наданих їй договором або актами цивільного законодавства, та дотримуватися моральних засад суспільства. У зв'язку з цим у статті запропоновано складники правової регламентації можливості здійснення власних активних дій суб'єктом в межах будь-якого суб'єктивного права, а також відповідно до сімейного законодавства авторами визначено межі здійснення прав та обов'язків батьків щодо виховання дитини.

Ключові слова: дитина, батьки, виховання, права дитини, охорона дитинства.

One of the important and significant achievements of civil society, of course, is the proclamation of the family rights and responsibilities of parents and children at the legislative level. Legislation establishes provisions on the priority of the interests of the child over the interests of the parents. Although the rights and responsibilities of both parents are equal and reciprocal, each parent must control the child's upbringing by the other party. Therefore, the article analyzes the problematic aspects and peculiarities of the implementation of the rights and obligations of parents in the upbringing of the child.

According to Art 12 of the Civil Code of Ukraine, a person exercises his civil rights freely, at his own discretion so the authors consider it necessary to clarify the concept of subjective law, while analyzing the views of other scholars and expressing their own views on the circumstances of the exercise of such rights.

According to the general rule envisaged by the Constitution of Ukraine, the existing rights and freedoms of a person may not be narrowed, but the freedom of the individual must be consistent with the freedom of others and the justified demands of society. In addition, a number of articles of the Constitution provide for the possibility of restricting

(C) МАЗУР В.В. - кандидат юридичних наук, доцент кафедри цивільного права і процесу (Національна академія внутрішніх справ)

(C) РЕЗВОВА О.В. - аспірант кафедри цивільного права і процесу (Національна академія внутрішніх справ) 
certain rights and freedoms of a person and a citizen in the presence of certain circumstances. In determining the moral boundaries of the exercise of subjective rights, human values must play a central role.

The civil law of Ukraine contains a general rule that sets limits on the exercise of civil rights. Yes, a person's civil rights must be exercised within the limits given to him by the treaty or by acts of civil law, and the moral principles of society must be respected. In this connection, the article proposes the components of legal regulation of the possibility of exercising their own active actions by the subject within the framework of any subjective law as a whole, and also in accordance with family law, the authors defined the limits of the exercise of the rights and obligations of parents in the education child in particular.

Key words: child, parents, education, child rights, child protection.

Вступ. На сучасному етапі розвитку українського суспільства проблема реалізації прав особистості, у тому числі ії особистих немайнових прав, набуває особливого значення та висуває нові вимоги до якості законів України, правових інститутів, їх значимості, ефективності, ступеня впливу на людські якості та хід розвитку суспільства. Адже сама цінність правової системи, iii досконалість значною мірою зумовлена тим, яке місце в ній займає особистість, яка роль їй відводиться, якими правами вона наділена, як вони реалізуються і які гарантії передбачені для реалізації цих прав.

Стан дослідження. Окремі аспекти проблематики здійснення прав та обов'язків батьків щодо виховання дітей досліджували чимало науковців, зокрема І.В. Жилінкова, В.П. Грибанов, Р.Б. Шишка, С.С. Алексєєв, М.В. Антокольська, Ф.П. Власенко, В.М. Вовк, Л.Ю. Голишева, В.Д. Гончаренко, Т.В. Ісакова, О.В. Квас, І.Г. Король, Н.М. Крестовська, Л.А. Кузьмичева, С.С. Лов'як, А.М. Нечаева, Н.С. Ніжнік, З.В. Ромовська, А.Й. Рогожин, В.А. Рясенцев, Г.М. Свердлов, В.I. Сергєєвич, О.М. Сліпушко, О.Д. Святоцький, О.І. Чистяков та інші.

Постановка завдання. Метою статті є аналіз специфіки реалізації прав та обов'язків батьків щодо виховання дитини, а також визначення меж їх здійснення.

Результати дослідження. Проголошення сімейних прав батьків і дитини на законодавчому рівні є значним досягненням громадянського суспільства. Як зауважує I.В. Жилінкова, в реальному житті формально мати право та набувати можливості реалізувати закладені в ньому правомочності - не завжди однакові явища. Тому самостійного значення набуває процес здійснення (реалізації) суб'єктивних цивільних прав, тих повноважень, які становлять його сутнісний, змістовний елемент [1, с. 91].

В.П. Грибанов наголошував, що будь-яке суб'єктивне право становить соціальну цінність лише остільки, оскільки його можна реалізувати, тобто скористатися можливостями, які надаються цим суб' єктивним правом, для задоволення матеріальних і культурних потреб уповноваженої особи [2, с. 22].

Р.Б. Шишка справедливо зазначає, що закріплення права в законі та приналежність його учаснику правовідносин не забезпечує повноти їх врегулювання. Особливо це має значення для прав людини, оскільки право, яке не може бути здійснене, є лише декларацією [3, с. 29].

Під суб'єктивним правом у спеціальній літературі прийнято розуміти належну суб'єкту цивільного обороту або законну можливість діяти відповідним чином [4, с. 21]. Посилаючись на В.Л. Яроцького, здійснення суб'єктивного цивільного права - це реалізація мір можливої поведінки уповноваженої особи шляхом здійснення належних їй правомочностей (права на власні дії, права на чужі дії та права на захист) [5, с. 254].

Відповідно до ст. 12 Цивільного кодексу України особа здійснює своє цивільне право вільно, на власний розсуд. Це означає, що суб'єкти цивільного права без будь-якого стороннього впливу і можливого тиску обирають варіант дозволеної поведінки, які полягають у реалізації належних їм правомочностей, що складають відповідне суб'єктивне право. Крім цього, вони вільно обирають порядок і способи здійснення суб'єктивних цивільних прав. При цьому відмова громадян і юридичних осіб від здійснення належних їм прав не тягне припинення цих прав, за винятком випадків, передбачених законом [6, с. 264].

Необхідно враховувати дві обставини. По-перше, деякі суб'єктивні права одночасно виступають в якості цивільно-правових обов'язків. Тому реалізація таких суб'єктивних прав залежить не тільки від власного розсуду уповноважених осіб, але й від вказівок закону. По-друге, у цьому випадку йдеться про конкретні суб'єктивні права, якими володіють фізичні та юридичні особи. Питання про розпорядження правами, які можуть виникнути у суб'єкта в майбутньому, 
повинно вирішуватися з урахуванням правила про те, що правочин, який обмежує можливість особи мати не заборонені законом цивільні права та обов'язки, є нікчемним.

Що ж стосується меж здійснення цивільних прав, то відповідно до ст. 22 Конституції України при прийнятті нових законів або внесення змін до чинних законів не допускається звуження змісту та обсягу існуючих прав і свобод. Конституція категорично забороняє внесення до неї змін, що порушують права та свободи громадян (ст. 157). Це положення розвивається в ст. 23 Конституції, згідно з якою кожна людина має право на вільний розвиток своєї особистості, якщо при цьому не порушуються права і свободи інших людей. Важливим $є$ розуміння співвідношення інтересів особи та інтересів суспільства, а також прав особи і колективу. Виходячи з цього, свобода особи має узгоджуватися зі свободою інших людей та обгрунтованими вимогами суспільства [7].

Поряд із цим у низці статей Конституції передбачена можливість обмеження деяких прав людини і громадянина за наявності певних обставин. Затверджуючи принцип вільної реалізації належних громадянам та юридичним особам суб'єктивних прав, чинне законодавство висуває й певні вимоги, які повинні бути дотримані при здійсненні таких прав. Зміст цих вимог неоднаковий, адже він залежить від характеру і призначення конкретних суб’єктивних прав.

У ст. 13 Цивільного кодексу України міститься загальне правило, яке встановлює межі здійснення цивільних прав, оскільки саме при здійсненні цивільних прав особа повинна дотримуватися моральних засад суспільства [8]. Це не означає, що цивільний закон прирівнює моральні норми до правових. Саме по собі порушення моральних норм не передбачає для учасників цивільно-правових відносин несприятливих юридичних наслідків, бо інакше тлумачення закону ігнорувало б відмінності, які існують між нормами права і моралі, адже останні не можуть служити нормативною базою регулювання відносин. Зміст зазначеної вимоги полягає у тому, що у визначенні моральних меж здійснення суб'єктивних прав основну роль повинні відігравати загальнолюдські цінності.

Для будь-якого носія суб’єктивного права, в тому числі особистого немайнового, цінність має не право, а можливість його реального здійснення. Здійсненням суб'єктивного цивільного права прийнято вважати здійснення уповноваженою особою можливостей, що складають зміст цього права [9, с. 379].

Здійснення цивільних прав тісно пов'язане з їх змістом. У зміст особистого немайнового права входять три правомочності суб'єкта: правомочність на здійснення власних активних дій (або утримання від таких); можливість вимагати від зобов'язаних осіб утриматися від порушення особистого немайнового права; можливість використання передбачених цивільним законодавством засобів захисту [10, с. 112-113].

Правова регламентація можливості здійснення власних активних дій суб'єктом у рамках будь-якого суб'єктивного права, у тому числі особистого немайнового, складається з двох складників: прямої вказівки на можливість здійснення певних дій і прямої заборони на здійснення певних дій.

Досі здійснення особистого немайнового права розглядалося з точки зору задоволення інтересу уповноваженої особи. Суб'єктивні цивільні права можуть здійснюватися будь-якими не забороненими законодавством способами. Традиційно цивільно-правова доктрина виділяє фактичні і юридичні способи здійснення цивільних прав. Під фактичними способами здійснення суб'єктивних цивільних прав розуміються дії (система дій) уповноваженої особи, які не мають ознак угод або інших юридичних значущих дій. Під юридичними способами здійснення суб'єктивних цивільних прав розуміються дії (система дій), які мають ознаки правочинів, або інші значущі в юридичному сенсі дії [9, с. 381].

Під здійсненням права слід розуміти систему дій, спрямованих на задоволення інтересу, що досягається за допомогою суб'єктивного права. В.С. Ем підкреслює, що, здійснюючи свої суб'єктивні права, суб'єкт переслідує досягнення певної соціально-економічної і юридичної мети, зокрема придбання майна, укладення правочинів тощо. Здійснення суб'єктивного цивільного права - це процес, у результаті якого суб'єкт цивільного права на основі наявної в нього правомочності задовольняє свої матеріальні і духовні потреби [11, с. 379].

Як правильно зазначає В.П. Грибанов, у будь-якому суб'єктивному праві і на будь-якій стадії його існування знаходить своє вираження сукупність громадських і особистих інтересів $[10$, c. 240]. Саме суб'єктивне право, так і та свобода, яка гарантується законом з метою реального здійснення права уповноваженою особою, не можуть бути безмежними. Всяке суб'єктивне право, будучи мірою можливої поведінки такої особи, має певні межі як за своїм змістом, так і за характером його здійснення. Ці межі можуть бути більшими або меншими, але вони існують завж- 
ди. Межі є невід'ємною властивістю будь-якого суб'єктивного права, бо за відсутності таких меж право перетворюється на свою протилежність - у свавілля, перестає взагалі бути правом [10, с. 22].

Відповідно до ст. 151 Сімейного кодексу України «Права батьків щодо виховання дитини» батьки мають переважне право перед іншими особами на особисте виховання дитини; право залучати до виховання дитини інших осіб, передавати ії на виховання фізичним та юридичним особам; право вибирати форми та методи виховання, крім тих, які суперечать закону, моральним засадам суспільства [12].

Відповідно до ч. 1 ст. 152 Сімейного кодексу України «Забезпечення права дитини на належне батьківське виховання» право дитини на належне батьківське виховання забезпечується системою державного контролю, встановленою законом. Дитина має право противитися неналежному виконанню батьками своїх обов'язків щодо неї. Ч. 1 та 2 ст. 155 Сімейного кодексу України визначають допустимі межі дій і вчинків, пов'язаних із сімейним вихованням. Заборона здійснювати батьківські права всупереч інтересам дитини є орієнтиром, якого треба дотримуватися в повсякденному житті, а також при вирішенні спорів, пов'язаних із вихованням дитини, наприклад спорів між матір'ю та батьком щодо місця проживання малолітньої дитини (ст. 161 Сімейного кодексу України). Таким чином, якщо буквально тлумачити ч. 1 ст. 151 Сімейного кодексу України, виходить, що з боку дітей виховання - це право, а з боку батьків виховання своїх дітей - їх і право, і обов'язок.

H.I. Матузов зазначав, що «обов'язок як необхідна, належна поведінка протистоїть у рамках певних правовідносин суб'єктивному праву; його призначення - створити фактичну можливість для здійснення суб'єктом свого права» [13, с. 237].

На думку А.С. Казанцевої, обов’язок батьків по вихованню дитини - «це міра належної поведінки, яка виражається в особистому впливі батьків на дитину, порівняння своїх дій із вимогами педагогіки, норм моральності та моралі, правил співжиття і права з метою виховання дитини» [14, с. 19]. 3 урахуванням висловлених позицій вчених можна дослідити проблеми взаємозв'язку права дитини на виховання та обов'язки батьків щодо реалізації права дитини на виховання.

Якщо брати до уваги ч. 1 ст. 152 Сімейного кодексу України, де зазначається, що дитина має права на виховання своїми батьками, забезпечення ії інтересів, всебічний розвиток, повагу до ії̈ людської гідності та ч. 1 ст. 150 цього Кодексу, що закріплює обов’язок батьків по вихованню своїх дітей, то видно, що тут простежується наявність двох правовідносин. Їх сутність полягає у виникненні відносних правовідносин з боку кожного з батьків до дитини. Таким чином індивідуальний обов'язок по вихованню дитини є як у батька, так і в матері.

Ч. 2 ст. 155 Сімейного кодексу України забезпечує в першу чергу інтереси дитини. Пріоритет інтересів дитини над інтересами батьків закріплений також у ст. 3 Конвенції ООН про права дитини. В усіх діях щодо дітей незалежно від того, здійснюються вони державними чи приватними установами, які займаються питаннями соціального забезпечення, судами, адміністративними чи законодавчими органами, особлива увага приділяється якнайкращому забезпеченню інтересів дитини.

Ч. 4 ст. 155 Сімейного кодексу України містить бланкетну норму. Вона не уточнює, яку саме відповідальність будуть нести батьки у зв'язку з ухиленням від виконання батьківських обов'язків. Передбачається існування моральної відповідальності та юридичної відповідальності, яка закріплена в різних галузях права (сімейне, цивільне, адміністративне, кримінальне). В першому випадку відповідальність тягне моральний осуд батьків, у другому - додаткові обтяження або покарання у встановленому законом порядку. Під додатковим обтяженням розуміють несприятливі для порушника прав наслідки, що виходять за межі примусового виконання обов'язку. Отже, законодавець не випадково в главі 13 Сімейного кодексу України звертається у всіх статтях, які стосуються здійснення батьківських прав, не до одного, а до двох батьків, за винятком ст.ст. 157-159 зазначеного кодексу (здійснення батьківських прав батьків, які проживають окремо від дитини).

Метою такого звернення є ідея законодавця про те, що для досягнення відповідного результату у вихованні неповнолітньої дитини необхідне спільне здійснення батьками своїх обов'язків по реалізації права дитини на виховання. У зв'язку з цим права і обов'язки у одного і в іншого з батьків не тільки рівні, але і взаємні. Вони складають зміст батьківських правовідносин між двома батьками по вихованню дитини. Право одного з батьків протистоїть обов'язку іншого не перешкоджати у здійсненні права на виховання дитини і навпаки. Але при цьому кожен із батьків повинен контролювати процес виховання дитини, що здійснюється іншою стороною. 
Виходить, що, закріплюючи за дитиною право на отримання нею виховання від своїх батьків, законодавець покладає на батьків права та обов'язки по реалізації цього права. Статті 150 та 151 Сімейного кодексу України визначають взаємні права і обов'язки батьків по вихованню своїх дітей. Взаємність батьківських прав і обов'язків по вихованню дітей є своєрідною гарантією для неповнолітніх дітей на отримання ними «повноцінного» виховання. У цих статтях Сімейного кодексу України законодавець покладає відповідальність на батьків за виховання і розвиток своїх дітей, оскільки вони зобов'язані піклуватися про здоров'я, фізичний, психічний, духовний і моральний розвиток неповнолітніх. На думку авторів, саме поняття виховання батьками своїх дітей включає в себе всі перераховані вище елементи, необхідні для повноцінного розвитку дитини. Процес виховання батьками своїх дітей не може існувати без перерахованих елементів розвитку, тому що основною його метою є виховання духовної, фізично і всебічно розвиненої моральної особистості.

Висновки. Якщо уявити процес виховання батьками своїх дітей, при якому, припустимо, відсутній один з елементів розвитку, то можна стверджувати, що батьки повністю не реалізують право дитини на виховання. Дитина не отримує право на виховання в повному обсязі, а значить порушується ії право на виховання, забезпечення інтересів, на всебічний розвиток. Право дитини жити і виховуватися в сім’ї реалізується у відносно, оскільки цьому праву відповідає обов'язок батьків ії виховувати та розвивати (ст. 150 Сімейного кодексу України). Крім того, у випадку неможливості здійснення цього права рідними батьками, закон покладає аналогічній обов'язок на усиновлювачів чи опікунів.

Виходить, що принцип взаємоповаги суб'єктами сімейних правовідносин один одного повинен бути закладений і в батьківських правовідносинах. Однак ч. 1 ст. 155 Сімейного кодексу України закріплює право дитини на повагу до ії людської гідності батьками, які в цих правовідносинах виступають як зобов'язані суб'єкти. Взаємне право і обов'язок дитини на повагу батьків у чинному сімейному законодавстві відсутнє. Також не передбачено в чинному Сімейному кодексі України принципу взаємоповаги батьками один одного при здійсненні ними батьківських прав і обов'язків.

\section{Список використаних джерел:}

1. Жилінкова I.В. Механізми здійснення окремих категорій суб'єктивних цивільних і сімейних прав. Приватноправові механізми здійснення та захисту суб' 'ктивних прав фізичних та юридичних осіб : монографія / В.Л. Яроцький, В.І. Борисова, І.В. Спасибо-Фатєєва, І.В. Жилінкова та ін.; за наук. ред. проф. В.Л. Яроцького. Харків : Юрайт, 2013. С. 89-115.

2. Грибанов В.П. Осуществление и защита гражданских прав. 2-е изд., стереотип. Москва : Статут, 2001. $411 \mathrm{c}$.

3. Шишка Р.Б. Здійснення прав на об'єкти авторського права. Проблеми здійснення та захисту суб 'єктивних циивільних прав : зб. наук. пр. / НАПрН України, НДІ приват. права і підприємництва; за ред. д-ра юрид. наук, акад. НАПрН України В.В. Луця. Київ : Право України, 2013. C. 29-33.

4. СвердлыкГ.А.,Страунинг Э.Л.Защитаи самозащитагражданскихправ. Москва, 2002.202 с.

5. Цивільне право України : підручник: у 2-х т. / Борисова В.І. (кер. авт. кол.), Баранова Л.М., Жилінкова І.В. та ін.; за заг. ред. В.І. Борисової, І.В. Спасибо-Фатєєвої, В.Л. Яроцького. Київ : Юрінком Інтер, 2004. Т. 1. 480 с.

6. Цивільне право України. Академічний курс : підруч. у двох томах / за заг. ред. Я.М. Шевченко. Т. 1. Загальна частина. Київ : Концерн «Видавничий Дім «Ін Юре», 2003. 520 с.

7. Конституція України : Основний Закон України від 28 червня 1996 року. Вiдомості Верховної Ради України. 1996. № 30. Ст. 141.

8. Цивільний кодекс України від 16 січня 2003 року. Відомості Верховної Ради України. 2003. № 40-41. Ст. 356.

9. Гражданское право : учебник / отв. ред. проф. Е.А. Суханов. 2-е изд., перераб. и доп. Москва : Волтерс Клувер, 2004. Т. 1.816 с.

10. Грибанов В.П. Пределы осуществления и защиты гражданских прав. Москва, 1972.208 с.

11. Сімейний кодекс України від 10 січня 2002 року. Відомості Верховної Ради України. 2002. № 21-22. СТ. 135.

12. Матузов Н.И. Правовая система и личность. Саратов : Издательство Саратовского университета, 1987. 295 с.

13. Казанцева А.Е. Обязанности и права родителей (заменяющих их лиц) по воспитанию детей и ответственность за их нарушение. Томск : Изд-во Том. ун-та, 1987. 144 с. 